of about 5-6 per cent deoxyribonucleic acid. The chapter on electron microscopy and fine structure of viruses is one of the best in the book; the illustrations are well reproduced and include many of the now almost 'classical' photographs. There follows a useful account of the multiplication of viruses and the application of tissue culture methods. Chapters on the spread of viruses, vectors and insect viruses are all, as might be expected, excellent. Latent infections, tumour viruses and the control of virus diseases are dealt with in further chapters, and finally there is a fascinating account of viruses as agents in the biological control of pests. There is a helpful list of literature for further reading and a short, somewhat arbitrary, index.

The book has been written from the point of view that 'virology' is one science and that viruses are viruses whether they come from plants, bacteria, insects, higher animals or indeed tumours. Illustrative examples have been drawn from as wide a range as possible. Inevitably in a book of this size, the author has had to be selective in his choice of material. The bacterial viruses receive perhaps less than due mention; there is, for example, no description of lysogeny in the chapter on latent infections. One might also have expected that the nucleic acids of viruses and their significance in terms of genetic 'coding' and protein structure would have been developed into a more prominent theme, particularly after the prefatory quotation from Wendell Stanley. These are, however, minor criticisms, for Dr. Smith has in fact managed to deal entertainingly with a very wide selection of topics. This book can be recommended to give someone coming from outside the subject a very clear idea of the present state of 'virology'.

H. S. BEDSON

\section{A VARISCAN AGGLOMERATE}

\section{Some Aspects of the Variscan Fold Belt}

Edited by Dr. Kenneth Coe. (Ten Lectures delivered to the Ninth Inter-University Geological Congress.) Pp. vii +163 . (Manchester: The University Press, 1962.) 30s. net.

THE ninth Inter-University Geological Congress was held in Exeter in January 1961 and has resulted in a well-illustrated, printed book, a more ample and durable memorial to this conference than a few typed sheets recording the previous eight. The Variscan Fold Belt is a huge subject and cannot be uniformly covered at such a meeting. The ten contributors have polished up some attractive pebbles, as it were, but their aggregate is a rather friable conglomerate.

The chapter on Variscan orogenic phases makes the easiest reading in the book, for Prof. Simpson has had the advantage of thoroughly disagreeing with many of the findings and conclusions of that grand-old-man of German geology, Prof. Hans Stille. Prof. Simpson's article includes a short précis of some pertinent paragraphs from the Grundfragen der vergleichenden Tectonik and recalls for us the origins of a controversy now some forty years old. Most of the chapters deal with definite regions within the old, wide, twisting mountain system. In the first, Prof. de Sitter outlines the geology, with the help of new maps and sections, of a western sector of the Pyrenees, the Asturian and Cantabrian ranges. $\mathrm{He}$ contrasts the structural style here, where a stack of thrust sheets occur, all of them carried to the north, with that in more easterly parts of the Pyrenees, where the style is nearly symmetrical and extensive thrust sheets are all but absent.

A stratigraphical emphasis marks Prof. Neville George's study of north-western Europe. The thesis is helped along by some profiles across Britain, one across Ireland and another through the north-east of France. Prof. Gill's Ireland is like Caesar's Gaul, divided into three parts, a peaceful north, a gently folded centre and a disturbed and much-jointed south. The near neighbours, Cornwall and Devon, have two chapters devoted to them by Drs. Goldring and Prentice, who provide an up-to-date review, considering new evidence, of the history of Upper Devonian and Carboniferous times in the south-west of England for which many a questing student will be grateful.

All these regional chapters impose a strain on the general reader's knowledge of geography, for he must be able to bring to mind named capes and bays, mountains and rivers. Some names must be sought in a gazetteer to help find them in the atlas if the argument is to be followed intelligently. This is an inherent difficulty, and many more maps would have been required here to make the book geographically self-contained. A chapter by Dr. Phillips on the value of an analysis of small-scale structures is illustrated by examples taken not only from south-western England but from German Variscan districts. Dr. Long arrives at 280 million years as a numerical value for the age of the Carboniferous-Permian granite of south-western England. Another chapter by Dr. Hosking discusses centres of mineralization within these granites and describes factors contributing to the pattern of distribution of the Cornish tin-veins. The book concludes unexpectedly in the United States with Prof. Boucot's discourse on the Silurian and Devonian as seen in the Appalachian Mountains. J. V. HaRrison

\section{ELEMENTARY SCIENTIFIC BIOGRAPHIES}

\section{The Universe at Large}

By Prof. Hermann Bondi. (Science Study Series, No. 12.) Pp. $154+12$ plates. (London: Heinemann Educational Books, Ltd., 1961.) 5s. net.

\section{Pasteur and Modern Science}

By Dr. René Dubos. (Science Study Series, No. 13.) Pp. 159. (London: Heinemann Educational Books, Ltd., 1961.) 5s. net.

The Watershed

A Biography of Johannes Kepler. By Arthur Koestler. (Science Study Series, No. 14.) Pp. $280+$ 8 plates. (London: Heinemann Educational Books, Ltd., 1961.) 6s. net.

7 HESE three books are the latest additions to the Science Study Series, which aims at providing a survey of physical science within the grasp of the young student or layman. They succeed in this aim.

Bondi's task is the most difficult. He deals with a difficult subject and robs it of its difficulties. He has the gift of being able to explain in qualitative terms topies the full treatment of which would involve very intricate mathematics, and he succeeds in giving an interesting outline of the state of our knowledge of such matters as the constitution of the stars, of 